\title{
Penggunaan Granulocyte Colony-Stimulating Factor pada Pasien Tumor Padat yang Mengalami Neutropenia
}

\author{
Rosary, Hikari Ambara Sjakti
}

Departemen Ilmu Kesehatan Anak, RS Dr Cipto Mangunkusumo, Fakultas Kedokteran Universitas Indonesia, Jakarta

\begin{abstract}
Infeksi yang terkait dengan neutropenia pasca kemoterapi merupakan salah satu penyebab morbiditas dan mortalitas yang cukup sering pada pasien kanker. Neutropenia pasca kemoterapi selain akan memperpanjang lama rawat dan meningkatkan risiko infeksi, juga menyebabkan tertundanya pemberian kemoterapi dan pengurangan dosis kemoterapi. Hal ini secara tidak langsung akan mempengaruhi kesintasan pasien. Hematopoietic growth-stimulating factor adalah sitokin yang mengatur proliferasi, diferensiasi dan fungsi sel hematopoietik. Penggunaan granulocyte colony-stimulating factor (G-CSF) dan granulocytemacrophage colony-stimulating foctor $(G M-C S F)$ saat ini banyak diteliti pada pasien kanker yang berisiko mengalami neutropenia. Pemberian G-CSF pada manusia menyebabkan peningkatan neutrofil yang bersirkulasi karena berkurangnya masa transit dari sel induk menjadi neutrofil matur, oleh karenanya zat ini sering dipakai untuk mengatasi neutropenia. Tujuan penulisan untuk mengetahui kegunaanya pada pasien tumor padat yang mengalami neutropenia. (Sari Pediatri 2010;11(6):428-33).
\end{abstract}

Kata kunci: G-CSF, neutropenia, kemoterapi, tumor padat, anak

$\mathrm{H}$ ubungan antara neutropenia dan infeksi merupakan salah satu penyebab utama morbiditas dan mortalitas pasien kanker yang mendapat kemoterapi yang bersifat mielosupresif. Pemberian segera antibiotik spektrum luas secara empiris dapat memperbaiki outcome pasien dengan demam neutropenia. Baik

\footnotetext{
Alamat korespondensi:

Dr. Hikari Ambara Sjakti, Sp.A. Divisi Hematologi Onkologi Departemen Ilmu Kesehatan Anak FKUI- RSCM Jl. Salemba no. 6, Jakarta 10430. Telepon: 021-3907744, 31901170 Fax.021-3913982
}

derajat dan durasi neutropenia merupakan faktor penting yang berhubungan dengan risiko dan outcome infeksi. Komplikasi neutropenia akibat kemoterapi menyebabkan perawatan yang lebih lama, juga menyebabkan banyak tertundanya atau direduksinya dosis kemoterapi yang dapat berpengaruh pada kesintasan pasien tumor padat. ${ }^{1,2}$

Hematopoietic growth-stimulating factors adalah sitokin yang mengatur proliferasi, diferensiasi, dan fungsi sel hematopoietik. Penggunaan granulocyte colony stimulating factor (G-CSF) dan granulocytemacrophage colony stimulating factor (GM-CSF) saat ini 
banyak diteliti pada pasien kanker yang berisiko terjadi neutropenia. Produksi dari lineage neutrofil diatur oleh G-CSF. Pemberian G-CSF pada manusia menyebabkan peningkatan neutrofil yang bersirkulasi dan bersifat dose-dependent karena berkurangnya masa transit dari sel induk menjadi neutrofil matur. Pemberian GM-CSF akan menstimulasi pertumbuhan koloni granulosit, makrofag, dan eosinofil. Beberapa contoh G-CSF adalah filgrastim dan lenograstim, sedangkan beberapa contoh GM-CSF adalah sargramostim dan molgramostim. Pemberian G-CSF atau GMCSF merupakan salah satu upaya untuk mengatasi neutropenia. ${ }^{3,4}$ Tujuan penulisan untuk mengetahui kegunaannya pada pasien tumor padat yang mengalami neutropenia.

\section{Kasus}

Empat orang pasien tumor padat dengan neutropenia yang mendapat G-CSF (filgrastim) dilaporkan selama dirawat di Departemen Ilmu Kesehatan Anak RS Dr.Cipto Mangunkusumo. Kasus pertama adalah anak $\mathrm{R}$, laki-laki, usia 2 tahun dengan tumor mixed germ cell yang telah mendapat kemoterapi cisplatin, vinblastin, dan bleomisin tiga siklus. Pasien telah mengalami dua episode neutropenia dengan absolute neutrophyl count (ANC) $51,7 / \mu \mathrm{L}$ dan $148 / \mu \mathrm{L}$ pasca-kemoterapi siklus pertama dan kedua, serta satu episode demam neutropenia dengan neutropenia berat pada pascakemoterapi siklus ketiga. Kemoterapi pada pasien tertunda satu kali akibat ditemukan neutropenia. Pasien mendapat filgrastim $2,5 \mu \mathrm{g} / \mathrm{kg}$ pada episode neutropenia kedua dan ketiga. Terdapat perbaikan neutropenia setelah pemberian 5 dan 7 hari.

Pasien kedua adalah anak F, laki-laki, usia 6 tahun dengan diagnosis limfoma non-Hodgkin. Pasien telah selesai mendapat kemoterapi protokol limfoma non-Hodgkin yang terdiri dari 6-merkaptopurin, metotreksat, vinkristin, siklofosfamid dan adriamisin selama 18 bulan. Selama menjalani kemoterapi, pasien mengalami sembilan episode neutropenia dan tiga episode demam neutropenia. Akibat neutropenia tersebut, kemoterapi pada pasien tertunda sembilan kali dan dosis kemoterapi direduksi sebanyak tiga kali. Dari 12 episode neutropenia, pasien mendapat filgrastim saat episode neutropenia ke-3 dan ke12. Filgrastim pada episode demam neutropenia ketiga diberikan dengan dosis $2 \mu \mathrm{g} / \mathrm{kg}$ selama 5 hari.
Perbaikan demam terlihat pada hari kedua dan terdapat peningkatan ANC dari $0 / \mu \mathrm{L}$ menjadi $13.348 / \mu \mathrm{L}$ pasca pemberian 5 hari. Filgastrim pada episode neutropenia terakhir diberikan untuk mencegah tertunda lebih lamanya kemoterapi pada pasien. Dosis filgrastim yang diberikan $4 \mu \mathrm{g} / \mathrm{kg}$ selama 4 hari memperbaiki jumlah leukosit dan pasien dapat menjalani kemoterapi yang sebelumnya tertunda.

Kasus ketiga adalah anak R, perempuan, usia 6 tahun dengan diagnosis osteosarkoma. Pasien sudah mendapat kemoterapi adjuvan yang terdiri dari cisplatin, ifosfamide, dan adriamisin, serta pembedahan. Pasien mengalami empat episode demam neutropenia. Pada episode demam neutropenia pertama yang terjadi saat kemoterapi siklus ketiga dengan derajat neutropenia berat, pasien mendapat terapi suportif tanpa pemberian filgrastim. Perbaikan demam terlihat dalam satu hari, namun perbaikan neutropenia baru terlihat pada hari ketujuh (ANC 1350/ $\mu \mathrm{L}$ ). Episode demam neutropenia kedua dengan ANC 66,7/ $\mu \mathrm{L}$ terjadi pasca-kemoterapi siklus keempat. Selain terapi suportif lainnya, pasien mendapat filgrastim dengan dosis $4 \mu \mathrm{g} / \mathrm{kg}$ selama dua hari. Suhu tubuh menjadi normal dan neutropenia membaik (ANC 2890/ $\mu$ L) pada hari ketiga. Saat jadwal masuk kemoterapi siklus keenam, pasien mengalami episode demam neutropenia ketiga dengan derajat neutropenia berat. Kemoterapi pada pasien ditunda, dan pasien mendapat filgrastim $2 \mu \mathrm{g} / \mathrm{kg}$ selama 3 hari. Pasca-pemberian filgrastim demam menghilang namun dijumpai neutropenia (ANC 1190/ $\mu$ L). Pascakemoterapi siklus keenam, pasien kembali mengalami demam dengan derajat neutropenia berat. Pasien mendapat filgrastim $2 \mu \mathrm{g} / \mathrm{kg}$ selama enam hari, namun pasien tetap demam dan mengalami neutropenia. Dosis filgrastim dinaikkan menjadi $2,5 \mu \mathrm{g} / \mathrm{kg}$ dan jumlah neutrofil meningkat terjadi setelah tiga hari pengobatan.

Pasien keempat adalah anak laki-laki K, usia 17 tahun dengan diagnosis karsinoma nasofaring telah mendapat kemoterapi yang terdiri dari cisplatin dan 5-fluorourasil, dilanjutkan radioterapi dengan chemosensitizer cisplatin. Pasien mengalami satu episode demam neutropenia pasca kemoradioterapi siklus ke-5 dengan derajat neutropenia berat. Empat hari pertama pasien hanya mendapat terapi suportif (antibiotik dan transfusi), demam menghilang dalam satu hari, namun tetap neutropenia. Setelah empat hari masih ditemukan neutropenia, pasien mendapat filgrastim $2 \mu \mathrm{g} / \mathrm{kg}$ selama lima hari. Pada pemberian

Sari Pediatrī, Vol. 11, No. 6, April 2010 
hari ketiga sudah terlihat peningkatan jumlah neutrofil (ANC $1771 / \mu \mathrm{L}$ ).

\section{Masalah klinis}

Neutropenia dengan atau tanpa demam merupakan kejadian yang cukup sering ditemukan pasien keganasan yang mendapat kemoterapi. Hal ini berakibat terjadinya infeksi, tertundanya ataupun berkurangnya dosis kemoterapi. Oleh karena itu G-CSF diberikan sebagai terapi pada pasien yang mengalami neutropenia, namun kegunaannya masih belum jelas. Berdasarkan hal tersebut, diajukan pertanyaan sebagai berikut: 'Pada pasien dengan tumor padat yang mengalami neutropenia, apakah pemberian G-CSF akan memberikan respons terapi yang lebih baik dibandingkan hanya terapi suportif?'

\section{Penelusuran}

Prosedur pencarian literatur untuk menjawab masalah klinis dengan menelusuri pustaka secara online dengan mempergunakan instrumen pencari Pubmed, Highwire, Cochrane Library, Google, dan Yahoo. Kata kunci yang dipergunakan neutropenia, febrile neutropenia dengan G-CSF, GM-CSF atau filgrastim dengan menggunakan batasan: studi yang dilakukan pada manusia, publikasi bahasa Inggris, kata kunci terdapat pada judul atau abstrak, serta jenis publikasi berupa uji klinis, uji klinis terandomisasi, meta-analisis, dan review. Penelusuran lebih lanjut secara manual dilakukan pada daftar pustaka yang relevan. Setelah penelusuran judul dan abstrak artikel-artikel tersebut, didapatkan 16 artikel yang relevan dengan enam artikel review. Levels of evidence ditentukan berdasarkan klasifikasi yang dikeluarkan oleh Oxford Centre for Evidence-based Medicine Levels of Evidence. ${ }^{5}$

\section{Hasil penelusuran}

Penelitian yang mempelajari kegunaan colonystimulating factor (CSF) pada pasien tumor padat dengan demam neutropenia umumnya menggunakan populasi dewasa. Hanya satu penelitian yang melaporkan pada pasien tumor padat dengan neutropenia tanpa demam. Tidak ada studi yang meneliti penggunaan CSF pada pasien anak dengan tumor padat saja, namun terdapat tiga studi yang meneliti pada populasi anak dengan tumor padat dan kanker hematologi. Sebagian besar studi menggunakan G-CSF, sedangkan GM-CSF ditemukan pada tiga artikel.

Semua penelitian menunjukkan hasil yang konsisten dalam durasi perbaikan jumlah neutrofil berbeda bermakna, yaitu kelompok CSF memiliki durasi yang lebih pendek dalam mencapai target ANC daripada kelompok plasebo. Hal ini misalnya terlihat pada studi multisenter di Spanyol oleh Garcia Carbonero $\mathrm{R} \mathrm{dkk}^{6}$ yang meneliti pasien tumor padat dengan demam (suhu $>38^{\circ} \mathrm{C}$ ) dan neutropenia $(\mathrm{ANC}<500 /$ $\mu \mathrm{L})$. Dua ratus tiga pasien dilakukan randomisasi, 104 pasien mendapat antibiotik dan G-CSF dosis $5 \mu \mathrm{g} /$ $\mathrm{kg}$, sementara 99 pasien menjadi kelompok kontrol yang hanya mendapat antibiotik. Hasil penelitian menunjukkan lama periode neutropenia berkurang $33 \%(\mathrm{p}<0,00004)$ (level of evidence: $1 \mathrm{~b})$.

Outcome hasil penelitian yang lain bervariasi antar studi. Garcia Carbonero R dkk ${ }^{6}$ menunjukkan terdapat durasi perawatan dan lama penggunaan antibiotik yang lebih pendek (masing-masing berkurang 29\% dan $17 \%)$ pada kelompok pasien yang mendapat G-CSF yang berbeda bermakna dari kelompok kontrol. Hasil yang berbeda ditunjukkan oleh Hartmann $\mathrm{dkk}^{7}$ yang meneliti pada 143 pasien tumor padat dengan neutropenia $(\mathrm{ANC}<500 / \mu \mathrm{L})$ tanpa demam yang dirandomisasi untuk mendapat G-CSF $5 \mu \mathrm{g} / \mathrm{kg}$ dan plasebo. Penelitian tersebut tidak menunjukkan perbedaan yang bermakna antara kelompok G-CSF dan plasebo dalam hal lama perawatan dan pemberian antibiotik (level of evidence: $1 \mathrm{~b}$ ).

Hampir semua penelitian menggunakan dosis CSF sebesar $5 \mu \mathrm{g} / \mathrm{kg}$, kecuali satu penelitian yang dilakukan oleh Maher DW $\mathrm{dkk}^{8}$ di Australia yang melakukan uji acak terkontrol pada 218 pasien demam (suhu $\left.>38,2^{\circ} \mathrm{C}\right)$ dan neutropenia $(\mathrm{ANC}<1000 / \mu \mathrm{L})$. Pada kelompok uji diberikan G-CSF (filgrastim) dengan dosis $12 \mu \mathrm{g} / \mathrm{kg}$ dengan median lama pemberian tujuh hari. Pada kelompok uji ditemukan durasi neutropenia yang lebih singkat, yaitu berkurang $25 \%$ pada pasien dengan derajat neutropenia berat $(\mathrm{ANC}<500 / \mu \mathrm{L})$ dan $40 \%$ pada pasien dengan derajat neutropenia sedang $(\mathrm{ANC}<1000 / \mu \mathrm{L})$, namun tidak terdapat perbedaan yang bermakna dalam lama perawatan, lama demam, dan pemberian antibiotik (level of evidence: $1 \mathrm{~b}$ ).

Salah satu studi pada populasi anak dilakukan oleh Mitchell PLR dkk ${ }^{9}$ yang meneliti anak dengan 
kanker dan mengalami demam (suhu $>38^{\circ} \mathrm{C}$ ) dan neutropenia (ANC $<500 / \mu \mathrm{L}$ ). Penelitian tersebut melakukan randomisasi pada 186 episode demam neutropenia. Kelompok uji (94 episode) mendapat G-CSF dengan dosis $5 \mu \mathrm{g} / \mathrm{kg}$. Perbedaan bermakna antara kelompok G-CSF dan plasebo ditemukan dalam hal lama rawat, lama terjadi neutropenia dan lama pemberian antibiotik, namun lama demam tidak menunjukkan hasil yang berbeda bermakna (level of evidence: 1b). Hasil studi yang hampir sama juga ditemukan oleh Ozkaynak MF dkk ${ }^{10}$ yang melakukan randomisasi pada 67 pasien anak dengan demam (suhu $>38,3^{\circ} \mathrm{C}$ ) dan neutropenia $(\mathrm{ANC}<500 / \mu \mathrm{L})$. Kelompok perlakuan 32 pasien mendapat antibiotik dan G-CSF 5 $\mu \mathrm{g} / \mathrm{kg}$, sedangkan 34 pasien mendapat antibiotik saja. Perbedaan hasil studi ini dengan Mitchell PLR dkk9 menunjukkan bahwa lama pemberian antibiotik tidak berbeda bermakna di antara kedua kelompok (level of evidence: $1 \mathrm{~b})$.

Riikonen $\mathrm{P} \mathrm{dkk}^{11}$ juga melakukan studi pada anak usia 6 bulan sampai 15 tahun dengan demam (suhu $>38^{\circ} \mathrm{C}$ ) dan neutropenia $(\mathrm{ANC}<200 / \mu \mathrm{L})$, namun yang diteliti adalah efek pemberian GM-CSF. Dari 58 episode demam neutropenia yang dirandomisasi, 28 episode mendapat GM-CSF dengan dosis $5 \mu \mathrm{g} /$ $\mathrm{kg}$. Hasil penelitian menunjukkan durasi neutropenia, perawatan, dan pemberian antibiotik yang lebih singkat pada kelompok pasien yang mendapat GMCSF $(\mathrm{p}<0,05)$, namun tidak terdapat perbedaan yang bermakna dalam lama demam (level of evidence: $1 \mathrm{~b}$ ). Hasil studi ini tidak sama dengan hasil penelitian yang dilakukan oleh Vellenga $E \mathrm{dkk}^{12}$ yang juga menggunakan GM-CSF pada 134 pasien kanker dengan demam (suhu $>38^{\circ} \mathrm{C}$ ) dan neutropenia $($ ANC $<500 / \mu \mathrm{L})$. Setelah dilakukan randomisasi, 65 pasien mendapat GM-CSF dosis $5 \mu \mathrm{g} / \mathrm{kg}$ dengan median lama pemberian 5 hari. Perbedaan yang bermakna $(\mathrm{p}<0,001)$ ditemukan dalam peningkatan jumlah neutrofil, namun tidak dalam lama demam, perawatan, dan pemberian antibiotik (level of evidence: 1b).

Pemberian GM-CSF pada pasien tumor padat menyebabkan lama rawat, lama infeksi serta pemberian antibiotik yang lebih singkat daripada pasien yang mendapat plasebo, namun hal tersebut tidak berbeda bermakna bila dibandingkan dengan kelompok pasien yang mendapat G-CSF. Hasil ini terdapat pada telaah sistematik yang dilakukan oleh Dubois RW $\mathrm{dkk}^{13}$ pada enam uji acak terkontrol yang membandingkan GM-
CSF dengan plasebo dan tiga studi membandingkan dengan GM-CSF dengan G-CSF (level of evidence: 1a).

Telaah sistematik lain dilakukan oleh Berghmans T dkk ${ }^{14}$ pada studi-studi tahun 1980-1999 mengenai pengunaan terapeutik G-CSF dan GM-CSF pada pasien kanker dengan demam neutropenia. Hasil penelitian menunjukkan tidak ada dampak menguntungkan yang berpengaruh pada mortalitas. Efektivitas pada lama demam, lama perawatan, dan mortalitas berhubungan dengan infeksi tidak konsisten, sehingga peneliti tidak merekomendasi penggunaan rutin CSF pada demam neutropenia (level of evidence: 1a). Meta-analisis yang lebih baru dilakukan oleh Clark OAC $\mathrm{dkk}^{15}$ terhadap 13 uji acak terkontrol juga menunjukkan angka mortalitas tidak berbeda secara signifikan pada penggunaan CSF, namun terdapat perbedaan bermakna dalam hal berkurangnya mortalitas yang berhubungan dengan infeksi, durasi perawatan lebih pendek dan peningkatan jumlah neutrofil. Lama demam dan penggunaan antibiotik jarang dilaporkan pada studi yang dibahas sehingga meta-analisis tidak dapat dilakukan (level of evidence: 1 a).

\section{Pembahasan}

Neutropenia pada pasien kanker sering disebabkan oleh efek mieloablatif kemoterapi sistemik, menyebabkan imunitas nonspesifik rentan terhadap mikroba patogen, sehingga meningkatkan risiko terjadi infeksi berat pasca-kemoterapi. Derajat neutropenia tergantung intensitas regimen kemoterapi dan jadwal pemberian. Risiko mortalitas berhubungan dengan derajat dan durasi neutropenia. Derajat neutropenia dapat dibagi menjadi derajat ringan (ANC 1000-1500/ $\mu \mathrm{L}$ ), sedang (ANC 500-1000/ $\mathrm{LL}$ ), dan berat $(\mathrm{ANC}<500 / \mu \mathrm{L}){ }^{16}$ Pada serial kasus yang ditampilkan demam neutropenia ditemukan pada pasien dengan derajat neutropenia berat (pasien kedua dengan ANC 0 dan pasien ketiga dengan ANC 66,7). Beratnya derajat neutropenia juga dipengaruhi oleh regimen kemoterapi. Regimen kemoterapi yang cukup berat, seperti protokol osteosarkoma (pasien kedua) dan limfoma non Hodgkin (pasien ketiga), juga mempengaruhi derajat neutropenia.

Demam neutropenia secara signifikan dapat mempengaruhi kelangsungan terapi akibat tertundanya 
atau reduksi dosis kemoterapi berikutnya. Hal ini dapat mempengaruhi pemberian kemoterapi yang optimal dan mengurangi respons terapi pasien yang dapat menyebabkan angka kesintasan yang lebih rendah. Suatu studi yang dilakukan oleh Oncology Hematology Group of South Florida pada 165 pasien kanker tahun 1998 menunjukkan adanya 38\% reduksi dosis dan $42 \%$ penundaan kemoterapi yang disebabkan oleh neutropenia. Setelah implementasi pedoman mengenai pemberian G-CSF, yang antara lain diberikan pada pasien dengan demam neutropenia dan pasien yang tertunda kemoterapinya karena neutropenia, pada tahun 2000 persentase reduksi dosis dan penundaan kemoterapi berkurang menjadi masing-masing 20\% dan $35 \% .{ }^{2}$ Hal yang sama terlihat terutama pada pasien kedua pada serial kasus. Pasien mengalami 12 episode neutropenia (dengan dan tanpa demam) dengan sembilan kali terdapat penundaan kemoterapi dan tiga kali dosis kemoterapi direduksi. Pasien pertama dan ketiga juga mengalami tertundanya kemoterapi akibat neutropenia. Apabila dari serial kasus dihitung secara total terdapat 20 episode neutropenia, maka terdapat $55 \%$ episode yang mengakibatkan tertundanya kemoterapi dan $15 \%$ episode yang menyebabkan dosis kemoterapi direduksi.

Pemberian G-CSF dapat meningkatkan jumlah neutrofil yang bersirkulasi yang bersifat dose-dependent terutama karena berkurangnya masa transit dari sel induk menjadi neutrofil matur. Sesuai dengan hasil penelusuran, sebagian besar literatur memakai dosis $5 \mu \mathrm{g} / \mathrm{kg} /$ hari. Beberapa artikel mencantumkan lama pemberian, yaitu pada umumnya 5-7 hari. Pada serial kasus dosis G-SCF yang diberikan berkisar antara 2 sampai $4 \mu \mathrm{g} / \mathrm{kg} /$ hari dengan lama pemberian 4-7 hari. Dosis yang relatif kurang adekuat bila dibandingkan dengan literatur ini pada sebagian besar kasus sudah dapat memperbaiki neutropenia pada pasien, namun terdapat satu pasien yang memerlukan peningkatan dosis dan baru menunjukkan perbaikan setelah sembilan hari perbaikan.

Penggunan CSF pada pasien onkologi dapat dipakai sebagai profilaksis primer (inisiasi CSF sebelum kejadian neutropenia), profilaksis sekunder (inisiasi CSF pada siklus kemoterapi setelah sebelumnya terdapat neutropenia atau demam neutropenia), dan terapi (insiasi CSF pada neutropenia dengan atau tanpa demam). ${ }^{17}$ Profilaksis G-CSF sekunder bersama dengan kemoterapi siklus berikutnya diberikan apabila terdapat riwayat demam neutropenia dan tertundanya kemoterapi karena neutropenia karena pada pasien tersebut rentan terjadi neutropenia kembali. Sebagai upaya preventif yang diberikan bersama kemoterapi, studi klinis G-CSF menunjukkan berkurangnya durasi neutropenia dan insidens demam neutropenia sampai $50 \% .^{2}$ Pada semua serial kasus yang ditampilkan, G-CSF digunakan sebagai terapi. Banyak pasien tumor padat yang tidak mendapatkan terapi G-CSF saat neutropenia karena keterbatasan biaya. Pemberian G-CSF sebagai profilaksis neutropenia tampaknya sulit diterapkan akibat alasan yang sama. Penggunaan profilaksis sulit dilakukan di negara berkembang karena harganya yang cukup mahal.

\section{Kesimpulan}

Pemberian G-CSF sebagai terapi pada pasien tumor padat dengan neutropenia secara bermakna dapat memperpendek lamanya neutropenia apabila dibandingkan dengan terapi suportif saja. Efek lain yang menguntungkan adalah mengurangi lamanya demam, lama perawatan, serta pemberian antibiotik, namun hal ini belum memberikan hasil yang konsisten. Pemberian G-CSF sebagai profilaksis dapat mengurangi insidens demam neutropenia dan episode neutropenia, sehingga dapat mengurangi kejadian tertundanya kemoterapi ataupun reduksi dosis kemoterapi maka pasien diharapkan akan memiliki kesintasan yang lebih baik.

\section{Daftar Pustaka}

1. Pascoe J, Cullen M. The prevention of febrile neutropenia. Curr Opin Oncol 2006;18:325-9.

2. White N, Maxwell C, Michelson J, Bedell C. Protocols for managing chemotherapy-induced neutropenia in clinical oncology practices. Cancer Nursing 2005;28:62-9.

3. Raposo CG, Marin AP, Baron MG. Colony-stimulating factors: Clinical evidence for treatment and prophylaxis of chemotherapy-induced febrile neutropenia. Clin Transl Oncol 2006;8:729-34.

4. Kaushansky K. Lineage-spesific hematopoietic growth factors. N Engl J Med 2006;354:2034-45.

5. Oxford Centre of Evidence-based Medicine. Oxford Centre for evidence-based medicine levels of evidence (March 2009). Diunduh dari: http://www.cebm.net/index. asox?o=1025. Diakses tanggal 22 Juli 2009. 
6. Garcia-Carbonero R, Mayordomo JI, Tornamira MV, Lopez-Brea M, Rueda A, Guillem V, dkk. Granulocyte colony-stimulating factor in the treatment of high risk febrile neutropenia: A multicenter randomized trial. J Natl Cancer Inst 2001;93:31-8.

7. Hartmann LC, Tschetter LK, Habermann TM, Ebbert LP, Johnson PS, Mailliard, dkk. Granulocyte colonystimulating factor in severe chemotherapy induced afebrile neutropenia. N Engl J Med 1997;336:177680

8. Maher DW, Lieschke GJ, Green M, Bishop J, StuartHarris R, Wolf M, dkk. Filgrastim in patients with chemotherapy-induced febrile neutropenia. Ann Intern Med 1994;121:492-501

9. Mitchell PLR, Marland B, Stevens MCG, Dick G, Easlea D, Meyer LC. Granulocyte colony-stimulating factor in established febrile neutropenia: A randomized study in pediatric patients. J Clin Oncol 1997;15:1163-70.

10. Ozkaynak MF, Krailo M, Chen Z, Feusner J. Randomized comparison of antibiotics with and without granulocyte colony-stimulating factor in children with chemotherapyinduced febrile neutropenia: A report from the children's oncology group. Pediatr Blood Cancer 2005;45:27480.

11. Riikonen P, Saarinen UM, Makipernaa A, Hovi L, Komulainen A, Pihkala J, dkk. Recombinant human granulocye-macrophage colony-stimulating factor in the treatment of febrile neutropenia: a double blind placebo-controlled study in children. Pediatr Infect Dis 1994;13:197-202

12. Vellenga E, Uyl-de Groot CA, de Wit R, Keizer HJ, Lowenberg B, ten Haaft MA, dkk. Randomized placebocontrolled trial of granulocyte-macrophage colonystimulating factor in patients with chemotherapy-related febrile neutropenia. J Clin Oncol 1996;14:619-27.

13. Dubois RW, Pinto LA, Bernal M, Badamgarav E, Lyman GH. Benefits of GM-CSF versus plasebo or G-CSF in reducing chemotherapy-induced complications: A systematic review of the literature. Supportive Cancer Therapy 2004;2:34-41.

14. Berghmans T, Paesmans T, Lafitte JJ, Mascaux C, Meert AP, Jacquy C, dkk. Therapeutic use of granulocyte and granulocyte-macrophage colony-stimulating factors in febrile neutropenic cancer patients. Support Care Cancer 2002;10:181-8

15. Clark OAC, Lyman G, Castro AA, Clark LGO, Djulbegovic B. Colony stimulating factors for chemotherapy induced febrile neutropenia. Cochrane Database Syst Rev 2009;3:CD003039

16. Schwartzberg LS. Neutropenia: Etiology and pathogenesis. Clinical Cornerstone 2006;8 (Suppl5):S5-11.

17. Smith TJ, Khatcheressian J, Lyman GH, Ozer H, Armitage JO, Balducci L, dkk. 2006 update of recommendations for the use of white blood cell growth factors: An evidence-based clinical practice guideline. J Clin Oncol 2006;24:3187-205. 